\title{
Growth and Carrageenan from Kappaphycus alvarezii (Doty) at Different Depths and Their Possible Application in Other Locations
}

\author{
Petrus A. Wenno ${ }^{1}$, Rajuddin Syamsuddin ${ }^{2}$, and Endang Jamal ${ }^{1}$ \\ ${ }^{1}$ Aquaculture Study Program, Pattimura University, Ambon, Indonesia \\ ${ }^{2}$ Faculty of Marine Sciences and Fisheries, Hasanuddin University, Makassar, Indonesia \\ Email Petrus A. Wenno: petrawenno@gmail.com
}

\begin{abstract}
s
Petrus A. Wenno, Rajuddin Syamsuddin, and Endang Jamal. 2016. Growth and Carrageenan from Kappaphycus alvarezii (Doty) at Different Depths and Their Possible Application in Other Locations. Aquacultura Indonesiana. 17(1): 20-25. This study aimed to evaluate the growth and yield of carrageenan from Kappaphycus alvarezii (Doty) cultured at different depths of water. The study lasted for 49 days, using two strains (green and brown), three initial weights $(50,100,150 \mathrm{~g})$, and five levels of depth $\left(1,2 \frac{1}{2}, 4,5^{1 / 2}, 7 \mathrm{~m}\right)$. The results showed significant differences between growth rate and yield of carrageenan on the three treatments $(P<0.01)$. The highest growth rate of both morphology types of green and brown occur on the same weight and depth i.e., at initial weight $100 \mathrm{~g}$ and depth $2 \frac{1}{2} \mathrm{~m}$, respectively at 5.68 and $6.05 \% /$ day. The yield of carrageenan is likely to increase in depth with the highest value at a depth of $7 \mathrm{~m}$, respectively $17.12 \%$ at green type and $14.63 \%$ at brown type. The results showed that reducing growth may increase the yield of carrageenan by the increasing of water depth. Based on these results, this study can be applied to another location as long as the quality of water allows farming activities.
\end{abstract}

Keywords: Carrageenan yield; Growth rate; Kappaphycus alvarezii

\section{Introduction}

Seaweed cultivation, particularly the type of eucheuma, has been commonplace in almost all the waters of Indonesia (Adnan and Porse, 1987). Generally these activities take place in the shallow water at a depth of about $10 \mathrm{~m}$, although not all shallow waters can be utilized. Cultivation of red seaweed Kappaphycus alvarezii requires space that continues to grow to meet the increase of market demand. Utilization of deep water for cultivation of seaweed can be done to substitute the shallow water in the future.

As an important economic commodity, seaweed production has the potential to be enhanced to meet global demand (Neish, 2009). While the utilization of the Indonesia waters for cultivation activities are still limited in shallow waters. According to Dahuri (2012), there are only $3 \%$ of available shallow water that have been exploited, but these conditions do not agree to the evenly in Maluku waters dominated by the deep waters. In general, the use of deep water for seaweed farming has not been done yet, because it has a number of obstacles related to the characteristics of water, cultivation technology, and environmental stress.

According to Neish (2009), Indonesia waters have a greater opportunity to increase the production of seaweed than other countries, when seen from a long coastline which is owned, the sea area, and its geographic position as one of the coral triangle group. While farming activities which take place continuously at the same location throughout the year, tends to cause a decrease in production, because it deals with the availability of nutrients in the long term. On the other hand, production of seaweed with vertically method in the water column is higher than the long line system placed along the shore line (Hurtado and Agbayani, 2002). By comparison, culturing seaweed with long line system reaches 5 tons/ha/crop (Dahuri, 2012), while with vertical method may reach 120 tons/ha/year (Hurtado and Agbayani, 2002).

There are a number of studies related to the growth and content of carrageenan in shallow water (Ohno et al., 1994; Hurtado et al., 2008; Naguit and Tisera, 2009), however not many are dealt with the topics in deep waters (Wenno et al., 2015). This study aims to determine the growth and carrageenan yield of $K$. alvarezii cultivated in deep waters using vertical long line methods and horizontal system which was carried out separately at different growing seasons.

\section{Materials and Methods}

\section{Location and Time of Activity}

Both studies were conducted in different locations and at different times, in which the first 
study was conducted in Takalar district, South Sulawesi during May-June 2012. A second study was performed in Central Maluku district, Maluku during May-June 2015. The difference between location and time research is needed in order to determine the ability of the waters and the possibility of applying the vertical farming method in new location at different culturing period.

\section{Seedling Preparation}

Red seaweed Kappaphycus alvarezii of green and brown strains obtained from cultivated areas in Takalar District, South Sulawesi. Because it comes from the same location, acclimatization period was conducted for three days before planting time. The good seedling is the young plants with pointy ends and conical shape (Neish, 2005). Seedlings with different initial weight then tied separately on nylon string and placed at different rafts. The raft was then placed in a different column of water and left for 49 days. While the second research was carried out in the Saparua bay, Maluku using brown strain seeds obtained from Buru district, Maluku. After three days acclimatization, the seedlings were placed at nylon string at horizontally position and left for 56 days.

\section{Farming Construction}

Hanging rafts were designed to replace hanging rope techniques (Hurtado et al., 2001) as suggested (Wenno et al., 2015). Each raft consists of two PVC pipes $(\mathrm{L}=200 \mathrm{~cm}, \varnothing=5$ $\mathrm{cm})$ filled with concrete cement mixture which served as ballast. Two PVC pipes were connected to by two pieces of wood (W x L: $200 \times 400 \mathrm{~cm}^{2}$ ) to form a rectangular raft. Ten pieces of nylon strings $(\varnothing=4 \mathrm{~mm})$ with the length of $4 \mathrm{~m}$ each were used to connect both pipes and functioned as a place for tying seeds. The distance between two strings as placed on raft was determined to $20 \mathrm{~cm}$. Each raft was hung in the water column with the assistance of four ropes $(\varnothing=10 \mathrm{~mm})$ under the buoy and placed at the different depth of $1,2.5,4,5.5,7 \mathrm{~m}$. The buoy was made of styrofoam material ( $\left.\mathrm{H} \times \mathrm{W} \times \mathrm{L}: 40 \times 50 \times 50 \mathrm{~cm}^{3}\right)$, covered with plastic net to prevent the material from being broken.

The construction of structure was made by placing first raft one meter below the water surface and then connecting it to the second raft, one and a half meter under the first one. The second raft was connected to the third, one and a half meter under the second and so on until reaching the fifth raft at a depth of $7 \mathrm{~m}$. The structure of hanging rafts was then tied to the anchor ropes $(\varnothing=12 \mathrm{~mm})$. Anchor was made out of several new flour sacks filled with sand and lowered to meet the bottom substrate. The number of sand sacks depends on the distance of bottom substrate and strong water movement. The stronger the water moving the more sacks were required. Seedlings of green and brown strains of $K$. alvarezii that already tied on strings were fastened on each raft. Seaweed seeds that tied to the span rope were installed in accordance to tie-tie technique as suggested (Msuya et al., 2007; Goes and Reis 2010). Each raft equipped with seeds from different initial weights $(50,100$, $150 \mathrm{~g})$, and tied to the twin knot rope ( $\varnothing 1 \mathrm{~mm}$ ). The distance between two nearest nodes of twin knot rope was established at $20 \mathrm{~cm}$ in all. Finally, seeds of both strains and different initial weights were placed on each raft and put at different depth of water for 49 days.

The increase in weight of plants was measured after 49 days of culture. Daily growth rates (DGR) were measured and expressed as the percent increase in fresh weight per day according to the formula (Hung et al., 2009):

$$
\begin{aligned}
\mathrm{DGR}= & {\left[(\mathrm{Wt} / \mathrm{Wo})^{1-\mathrm{t}}-1\right] \times 100 } \\
\text { Where: } \mathrm{Wo}= & \text { initial fresh weight }, \\
\mathrm{Wt}= & \text { fresh weight at day } \mathrm{t}, \text { and } \mathrm{t}=\text { time } \\
& \text { interval }(7 \text { days }) .
\end{aligned}
$$

Accordingly, the measurement of carrageenan yield was performed as followed (Hayashi et al., 2007; Hung et al., 2009):

$$
\mathrm{YC}=(\mathrm{WC} / \mathrm{Wdw}) \times 100
$$

Where: $\mathrm{YC}=$ carrageenan content $(\%)$;

$\mathrm{WC}=$ weight of carrageenan extract $(\mathrm{g})$;

$\mathrm{Wdw}=$ dry weight of analysed thalus $(\mathrm{g})$.

For comparison, the second study was conducted in deep water of Saparua bay, Maluku. The study was based on growing data of $K$. alvarezii, using the same procedure as for DGR and carrageenan yield with the initial weight of $50 \mathrm{~g}$ of brown strain. Seeds were placed vertically on long line string at three meters depth and leaved to stand in the sea for 56 days. This construction was designed to reduce the effect of winds and waves which sometimes caused some plants broken and detached from its colony (Figure 1).

\section{Data Analysis}

Analysis of data was based on three factors of variance according to Zar (1999), and 
was performed with SPSS version 21 software. Subsequent analysis with Tukey's HSD test was computed when there were significant differences among treatments with the level of significance $(P<0.01)$.

\section{Results}

Daily growth rate (DGR) of green strain at the initial weight of $50 \mathrm{~g}$ was the highest occurred at $1 \mathrm{~m}$ depth during the first week as big as $4.41 \%$ followed by DGR at other depths, while DGR for the second to seven week tended to be uniform, but increased during the second week with the highest value at $1 \mathrm{~m}$ depth. Daily growth rate at the initial weight of $100 \mathrm{~g}$ was highest occurred at $2.5 \mathrm{~m}$ depth during the first week (8.58\%) followed by DGR at $1 \mathrm{~m}$ depth $(6.49 \%)$ and other depths, while DGR of the second to seventh week tended to diminishing with the highest value at $1 \mathrm{~m}$ depth. Daily growth rate at the initial weight of $150 \mathrm{~g}$ was highest occurred at $1 \mathrm{~m}$ depth $(4.07 \%)$ followed by DGR at other depths, while DGR of the second to seventh week tended to be uniform to third week with the highest value at $1 \mathrm{~m}$ depth with the exception at 2.5 depth of sixth week $(2.75 \%)$. The average DGR for all initial weight occurred between 4.27 and 5.68\% with the highest at $2.5 \mathrm{~m}$ depth (Table 1).

Daily growth rate of brown strain at the initial weight of $50 \mathrm{~g}$ was highest occurred at 2.5 $\mathrm{m}$ depth during first week as big as $7.56 \%$ followed by DGR at $4 \mathrm{~m}$ depth $(6.26 \%), 1 \mathrm{~m}$ depth $(6.4 \%)$ and other depths, while DGR of second to seventh week tend to be uniform, but increased during the second to fourth week with the highest value at $2.5 \mathrm{~m}$ depth, followed by $1 \mathrm{~m}$ depth during seventh week. Daily growth rate at the initial weight of $100 \mathrm{~g}$ was highest occurred at $2.5 \mathrm{~m}$ depth during first week $(8.74 \%)$ followed by DGR at $4 \mathrm{~m}$ depth (8.05\%), $1 \mathrm{~m}$ depth $(7.76 \%)$ and other depths, while DGR of second to seventh week tends to diminish to third week with highest value at $2.5 \mathrm{~m}$ depth followed by DGR at $1 \mathrm{~m}$ depth with the exception at $2.5 \mathrm{~m}$ during seventh week. Daily growth rate at the initial weight of $150 \mathrm{~g}$ was highest occurred at 1 $m$ depth $(7.35 \%)$ followed by DGR at other depths, while DGR of second to seventh week tended to be uniform up to third week with all highest value at $1 \mathrm{~m}$ depth with the exception at 2.5 depth of sixth week $(2.75 \%)$. The average DGR for all initial weight occurred between 5.10 to $6.05 \%$ with the highest one at $2.5 \mathrm{~m}$ depth (Table 1).

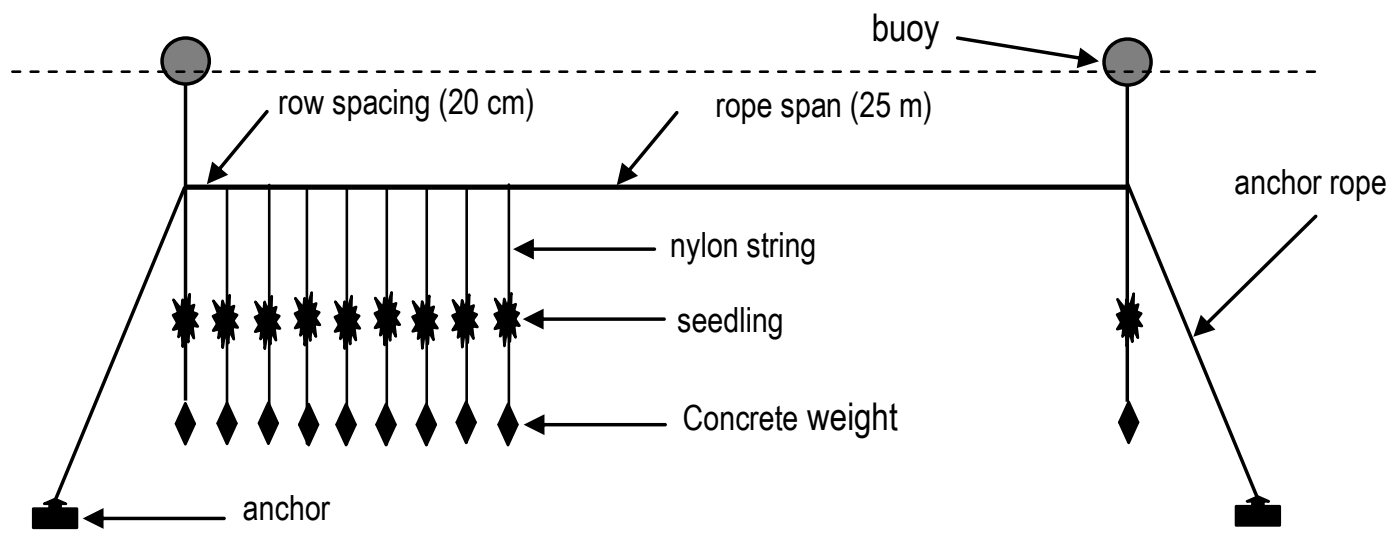

Figure 1. The construction scheme for seaweed farming

Table 1 . The average daily growth rate and carrageenan yield of both green and brown types of Kappaphycus alvarezii

\begin{tabular}{ccccc}
\hline \multirow{2}{*}{$\begin{array}{c}\text { Depth } \\
(\mathrm{m})\end{array}$} & \multicolumn{2}{c}{ Green morphology type } & \multicolumn{2}{c}{ Brown morphology type } \\
\cline { 2 - 5 } & DGR (\%/day) & Yield of car. (\%) & DGR (\%/day) & Yield of car. (\%) \\
\hline 1 & 5.53 & 14.43 & 5.81 & 10.64 \\
2.5 & 5.68 & 15.54 & 6.05 & 14.11 \\
4 & 5.17 & 15.50 & 5.77 & 13.03 \\
5.5 & 4.80 & 17.08 & 5.51 & 14.43 \\
7 & 4.27 & 17.12 & 5.10 & 14.63 \\
\hline
\end{tabular}


Meanwhile in the second study, DGR was likely to increase according to the culture period. Daily growth rate enhanced from fifth to eighth week as big as $4.83 \% ; 4.87 \% ; 4.98 \%$ and $4.69 \%$ respectively; or $4.84 \%$ on average.

The results showed the average yield of carrageenan at 14.43 to $17.12 \%$ for green strain and 10.64 to $14.63 \%$ for brown strain. It was appeared that DGR reduced according to the water depth, while the yield of carrageenan improved accordingly. This finding is contrary to the carrageenan yield which increases with the increasing DGR for seaweed cultivated with long line method (Hurtado et al., 2008).

\section{Discussion}

\section{Daily Growth Rate}

Daily growth rate of Kappahycus alvarezii showed interaction between strain and initial weight, strain and depth, as well as the initial weight and depth which was highly significant $(P<0.01)$, but no significant effect between strains, the initial weight and depth $(P>0.05)$. Further test showed that the highest daily growth rate of green and brown strains was obtained at the initial weight of $100 \mathrm{~g}$, which tend to be the same $(2.84 \%)$. It was related to the density of plant (Hurtado et al., 2008), leading to rapid growth in the initial weight. Daily growth rate at the initial weight of $100 \mathrm{~g}$ was influenced by the interaction between solar radiation, temperature, nutrient and water movement (Santelices, 1999), and causing absorption of nutrients faster than other initial weights. Absorption of nutrients was influenced by the density of plants (Azanza-Corrales et al., 1996).

Daily growth rate of $K$. alvarezii of green and brown strains tend to be the same. The highest similarity daily growth rate in green strain was achieved at the depths of 1 and $2.5 \mathrm{~m}$ $(2.55 \%)$, and the lowest one was at $7 \mathrm{~m}$ depth $(2.23 \%)$. The highest similarity daily growth rate in brown strain was also achieved at the depth of 1 and $2.5 \mathrm{~m}(2.83 \%)$, and the lowest one was at a depth of $7 \mathrm{~m}(2.57 \%)$. The highest daily growth rate of green and brown strains associated with the movement of water (Santelices, 1999). The movement of the water at that depth was turbulent, consequently reduce the thickness of water that is not mixed in the boundary layer (Neish, 2005), and the absorption of nutrients in this depth is faster. Glenn and Doty (1990) suggested that the absorption of nutrients during the fast flowing water among the plant canopy is higher for ammonium at a lower depth than for nitrate at the higher depth. The absorption of ammonium by seaweed is more important than nitrate (Dy and Yap, 2001; Raikar and Wafar, 2006). Similarly to DGR of $K$. alvarezii in first study, the second study with brown strain showed the interaction between strain and initial weight at the same depth which was highly significant $(P<0.01)$.

\section{Carrageenan Yield}

The yield of carrageenan in $K$. alvarezii shows the interaction between strain and initial weight, strain and depth, as well as the initial weight and depth and was highly significant $(P<0.01)$, but not significant by the interaction among the strains, the initial weight and depth $(P>0.05)$. Carrageenan yield of green strain was obtained higher with increasing depth. The carrageenan yield of green strain increased as $14.43 \%$ at $1 \mathrm{~m}$ depth, followed by $15.54 \%$ at 2.5 $\mathrm{m}, 15.50 \%$ at $4 \mathrm{~m}, 17.08 \%$ at $5.5 \mathrm{~m}$, and $7.12 \%$ at $7 \mathrm{~m}$ respectively; while the carrageenan yield of brown strain was observed lower than those in the green strain at the same depths. The yield of brown strain increased as $10.64 \%$ at $1 \mathrm{~m}$ depth, followed by $14.11 \%$ at $2.5 \mathrm{~m}, 13.03 \%$ at $4 \mathrm{~m}$, $14.43 \%$ at $5.5 \mathrm{~m}$, and $7.12 \%$ at $7 \mathrm{~m}$ respectively. The highest yield of carrageenan in green strain was obtained at a depth of $5.5 \mathrm{~m}(17.12 \%)$ and in brown strain at the depth of $7 \mathrm{~m}(14.63 \%)$. The highest yield of carrageenan is the result of the interaction between depth and the initial weight. The results showed that the yield of carrageenan in both strains was in line with the DGR.

Most of processing industries are very enthusiastic to have seaweed with higher carrageenan yield. It appeared in this study that DGR of brown strain was higher than those of Adnan and Porse (1987) at 2.5-3.5\% and Hurtado-Ponce et al. (1996) at 2.3 to $4.2 \%$; but lower than those of Muñoz et al. (2004) at 6.5\%; and Lim and Porse (1981) at 5.7\%. The results also showed that long maintenance period did not cause DGR to increase. On the contrary, the same DGR could not be the benchmark that the harvest should be done quickly than was expected. The growth based on DGR is important, because it illustrates the yield that one can obtain for a specific purpose, such as harvesting plants in the short time for having seeds.

The carrageenan yields in this study was lower at $14.73-30.79 \%$ compare to Hayashi et al. 
(2007) at $31-43 \%$ for SRC (semi refined carrageenan), and relatively higher than those at $25-28 \%$ for RC (refined carrageenan). This finding suggests the use of deep water for seaweed culture in the future.

\section{Conclusions}

Daily growth rate of $K$. alvarezii green and brown strains was influenced by the initial weight and tend to be reduced by the increasing of depth. However, the yield of carrageenan increased according to depth with the highest one was observed to occur at green strain compared to brown strain. One may recommend the use of deep water as the best area for seaweed culturing in the future.

\section{Acknowledgement}

These studies were supported by BPPS grant and MP3EI Grant from Directorate General Strengthening of Research and Development Ministry of Research, Technology and Higher Education of Republic of Indonesia. The author would like to thanks Mr. Daeng Bani the seaweed fisher and Mr. Reuben Umpenawany the field staff for all the help during this study. Special thanks to Ms. Difna Hatane for her assistance in preparing additional research data.

\section{References}

Adnan H. and H. Porse. 1987. Culture of Eucheuma cottonii and Eucheuma spinosum in Indonesia. Hydrobiologia, 151/152:355-358.

Azanza-Corrales, R., T.T. Aliaza, and N.E. Montano. 1996. Recruitment of Eucheuma and Kappaphycus on a farm in Tawi-Tawi, Philippines. Hidrobiologia, 326/327: 235244.

Dahuri, R. 2012. Cetak Biru Pembangunan Kelautan dan Perikanan. Menuju Indonesia yang Maju, Adil-Makmur, dan Berdaulat. Roda Bahari, Bogor. 134 pp (Indonesian version).

Dy, D.T. and H.T. Yap. 2001. Surge ammonium uptake of the cultured seaweed, Kappaphycus alvarezii (Doty) Doty (Rhodophyta, Gigartinales). J. Exp. Mar. Biol. Ecol. 265: 89-100.

Glenn, E.P. and M.S. Doty. 1990. Growth of the seaweeds Kappaphycus alvarezii, $K$. striatum and Eucheuma denticulatum as affected by environment in Hawaii. Aquaculture, 84: 245-255.

Goes, H.G. and R.P. Reis. 2010. What is the best technique for Kappaphycus alvarezii farming at the Soutn coast of Brazil? XX International
Seaweed Symposium. Eusenada Baja California Mexico. Feb. 22-26.

Hayashi, L., E.J.D. Paula, and F. Chow. 2007. Growth rate and carrageenan analyses in four strains of Kappaphycus alvarezii (Rhodophyta, Gigartinales) farmed in the subtropical water of Sao Paulo State, Brazil. J. Appl. Phycol. 19: 393-399.

Hung, L.D., K. Hori, H.Q. Nang, T. Kha, and L.T. Hoa. 2009. Seasonal changes in growth rate, carrageenan yield and lectin content in the red alga Kappaphycus alvarezii cultivated in Camranh Bay, Vietnam. J. Appl. Phycol. 21: 265-272.

Hurtado-Ponce, A.Q., R.F. Agbayani, and E.A.J. Chavoso. 1996. Economics of Cultivating Kappaphycus alvarezii using fixed-bottom line and hanging-long line methods in Panagatan Cays, Caluya, Antique, Philippines. J. Appl. Phycol., 105: 105-109.

Hurtado, A.Q., R.F. Agbayani, R. Sanares, and M.T.R. Castro-Mallare. 2001. The seasonality and economic feasibility of cultivating Kappaphycus alvarezii in Panagatan Cays, Caluya, Antique, Philippines. Aquaculture, 199: 295-310.

Hurtado, A.Q. and R.F. Agbayani. 2002. Deep-sea farming of Kappaphycus alvarezii using the multiple raft, long-line method. Bot. Mar., 45: 438-444.

Hurtado, A.Q., A.T. Critchley, A. Trespoey, and G. Bleicher-Lhonneur. 2008. Growth and carrageenan quality of Kappaphycus striatum var. sacol grown at different stocking densities, duration of culture and depth. $J$. Appl. Phycol., 20: 551-555.

Lim, J.R. and H. Porse. 1981. Breakthrough in the commercial culture of Eucheuma spinosum in Northern Bohol, Philippines. In: Levring, T. (Ed.), Proceedings of the $10^{\text {th }}$ International Seaweed Symposium. Walter de Grayter, Berlin, pp., 601-606.

Msuya, F.E., M.S. Shalli, K. Sullivan, B. Crawford, J. Tobey, and A.J. Mmochi. 2007. A Comparative Economic Analysis of Two Seaweed Farming Methods in Tanzania. The Sustainable Coastal Communities and Ecosystems Program. Coastal Resources Center, University of Rhode Island and the Western Indian Ocean Marine Science Association. 27p.

Muñoz, J., Y. Freile-Pelegrin, and D. Robledo. 2004. Mariculture of Kappaphycus alvarezii (Rhodophyta, Solieriaceae) color stains in tropical waters of Yucatan, Mexico. Aquaculture, 239: 161-177.

Naguit, M.R.A. and W. Tisera. 2009. Pigment analysis on Eucheuma denticulatum (Collins \& Hervey) and Kappaphycus alvarezii (Doty) 
cultivars cultured at different depths. The Treshold, IV: 29-37.

Neish, I.C. 2005. The Eucheuma Seaplant Handbook Volume I. Agronomics, Biology and Crop System. SEAPlantNet Technical Monograph No. 0505-10A. Makassar.

Neish, I.C. 2009. Tropical Red Seaweeds as a Foundation for Integrated Multi Tropic Aquaculture (IMTA) Four Propositions and an action plan for this major opportunity in the Coral Triangle. SEAPlant.net Monograph no. HB2E 1209 V3 IMTA.

Ohno, M., D.B. Largo, and T. Ikumoto. 1994. Growth rate, carrageenan yield and gel properties of cultured kappa-carrageenan producing red alga Kappaphycus alvarezii
(Doty) Doty in the subtropical waters of Shikoku, Japan. J. Appl. Phycol., 6 (1): 1-5.

Raikar, V. and M. Wafar. 2006. Surge ammonium uptake in macroalgae from a coral atoll. $J$. Exp. Mar. Biol. Ecol., 339: 236-240.

Santelices, B. 1999. A conceptual framework for marine agronomy. Hydrobiologia, 398/399: 15-23.

Zar, J.H. 1999. Biostatistical analysis. 4th Edition. Prentice Hall International, Inc. Internation Edition, 663 pp.

Wenno, P.A., R. Syamsuddin, E.N. Zainuddin, and R. Ambo-Rappe. 2015. Cultivation of red seaweed Kappaphycus alvarezii (Doty) at different depths in South Sulawesi, Indonesia. AACL Bioflux, 8 (3): 468-473. 